\title{
On Consecutive Interpreting of Chinese Promotion Roadshows of Government Investment Attraction Under Eco-translatology
}

\author{
SHA Lei \\ Binzhou University, Binzhou, China
}

\begin{abstract}
Along with the constant deepening of the "Belt and Road Initiative", the promotion roadshows of government investment attraction have been increasingly important in investment promotion and advertising propaganda. As one translation theory of the new perspective in recent years, eco-translatology can be applied as a new thought to guarantee a complete success of the consecutive interpreting task in the promotion of government investment attraction. From the perspective of eco-translatology, this paper expounds the methods of consecutive interpreting task improvement in the dimensions of linguistics, culture, and communication to further enhance the role of the Chinese promotion roadshows of government investment attraction.
\end{abstract}

Keywords: eco-translatology, promotion roadshows of government investment attraction, consecutive interpreting

\section{Introduction}

In recent years, China has launched its "Belt and Road Initiative" and as a result, the promotion of government investment attraction gives greater impetus for China's opening and cross-border communication. Among various public places like exhibition halls, luxury hotels, and stadiums, there are promotion activities at all levels and forms, mainly aiming to promote the basic information of regional economy, politics, and culture to its potential cooperation partners. Limited to many factors like sites, facilities, and interpreters, consecutive interpreting is still the most widely accepted working approach of promotion of government investment attraction and blamed for its unstable output quality and unauthorized assessment criteria. At the beginning of 21st century, Professor HU Geng-shen from Tsinghua University first put forward the theory of eco-translatology, a brand-new research perspective of translation and interpreting. This article will be discussed under this view about relevant consecutive interpreting studies of promotion roadshows of government in China. There are adapted examples and their analytical studies of some representative texts to further probe into the roles that interpreters should play in this type of activities.

\section{Consecutive Interpreting and Promotion Roadshows of Government Investment Attraction}

Interpreting or interpretation is an activity of translation from the source language to the target language, which is based on the input of a one-time utterance exposure from the speaker. Besides simultaneous interpreting, sign-language interpreting, whispering interpreting, and sight interpreting, consecutive interpreting is another working mode of interpreting and is performed when source language exposure happens, including

SHA Lei, teaching assistant, master of Interpreting and Translation, Foreign Languages School, Binzhou University, Binzhou, China. 
the interpreting task and psychological activity of the interpreter (WANG, 2016).

According to Professor Daniel Gile, the activity of consecutive interpreting can be divided into two phases: The first is listening and information receiving technique, which includes the listening and analysis of the speeches, note-taking, and short-term memory working; the second is target language output, including recalling the speech contents of the speaker, notes reading, and output (Gile, 2011). In promotion roadshows of government investment attraction, there are three operating features in actual activities: seriousness, correctness, and complexity. As the iconic image of local governments, its seriousness leads to a thorough and orderly process; its correctness represents the wide range of relevant fields and mass data of economic, political, and cultural development, thus further highlighting the regional characteristics and investment intention; its complexity can be observed in the terminology, buzzwords, and jargons of the speeches, as well as the impromptu speeches which are short of simplicity for the audience.

\section{Eco-translatology and Promotion Roadshows of Government Investment Attraction}

Through the experience of previous rational thinking and humanistic thoughts, Charles Darwin gradually became a student of nature and found his theory of evolution based on natural selectivity in 19th century. For the theory of eco-translatology, adaptive selectivity in Darwin's theory is chosen as the theoretical framework by Professor HU Geng-shen to further explore translation as under the guidance of ecological holism. With its aim of renewal research in translation studies, eco-translatology is designed to discuss various phenomena of translation activities, such as essential attributes, working process, evaluation criterion, translation principles and methods, and finally provide optional and feasible solutions.

However, the characteristics of consecutive interpreting determine that the interpreter is unable to fully adapt to different circumstances in the actual tasks and it is difficult to make his or her own adaptive choice transformation for all situations. Within the core framework of eco-translatology, "three-dimensional" transformation occupies a pivotal position. The so-called "three dimensions", namely, linguistic, cultural, and communicative dimensions, are all in the process of translation and in the choice of adaptability of each other (WANG, 2011). To convert the application and the conversion of all the multi-dimensional adaptation and adaptive selection, the translation process should be performed cyclically to alter the two conversions above. Promotion roadshows of government investment attraction ask consecutive interpretation to work under this framework with systematic processing and reliable adaptability and guarantee the good quality of interpreting tasks.

Three-dimensional transformation of eco-translatology not only provides the reference basis of the specific interpreting scene, but more importantly, the interpreter in the promotion roadshows of government investment attraction with linguistic, cultural, and communicative interactions. Through analytical studies of relevant cases, interpreting approaches and methods could be found and taken as reference.

\section{Application of "Three-Dimensional" Transformation in the Interpreting of Promotion Roadshows of Government Investment Attraction}

In the following analysis of interpreting cases of promotion roadshows of government investment attraction, detailed explanations and interpreting reference answers will be provided under the guidance of linguistic, cultural, and communicative dimensions. 


\section{Adaptive Selection and Transformation Strategies From Linguistic Dimension}

In language adaptive selection transformation, the interpreter needs to choose the adaptability of language form conversion during interpreting process, which exists in different aspects and at all levels (HU, 2009). In view of this, the interpreter at the beginning of the interpreting task should first establish the corresponding task background, select and actively adapt to the environment, and summarize the characteristics of the promotion roadshows of government investment attraction, using the related theory of eco-translatology to support for interpreting to coincide with the interpreting output selection and task environment successfully. This section selects the three typical interpreting conversion cases in the promotion roadshows of Canton Fair in 2016. The detailed analysis and reference interpretation are as follows:

Source Text of Example (1): 我们力推的目前有25个合作项目, 这些都是我市的拳头产品和支柱产业, 建设基础优秀, 发展前景良好, 大部分前期工作已完成。

Reference Interpreting: There are altogether 25 cooperation projects at present, which cover our blockbusters and pillar industry. With a good foundation of construction and development, we are glad to announce that most preliminary work has been finished.

In the promotion roadshows of government investment attraction, many contents are related to the introduction and elaboration of cooperation projects. In this case, it is not difficult to understand the structure of a sentence from the linguistic dimension. In view of this, the interpreter should mainly consider how to express the meaning of the source text from the pragmatic level and highlight the core words meaning in source language, such as “拳头产品” and “支柱产业”, which can be translated into "blockbuster" and "pillar industry". This strategy could highlight the importance of cooperation projects with the sentence structure in the grasp of the ecological environment of the source language. At the same time, the differences of the ecological environment are also taken care of in the target language.

Source Text of Example (2): 多年以来, 我市已经形成了陶瓷加工、机械零部件加工、鱼类养殖为代 表的三大传统优势产业和信息工程、航空航天、可再生能源三大新兴产业。

Reference Interpreting: Our city has established three traditional pillar industries of ceramic machining, mechanical parts processing and fish farming along with three emerging industries of information engineering, aerospace and aviation and renewable energy.

In the process of language transformation, interpreters often make mistakes mainly in the choice of the form of target language. Because of the differences between source language and target language, interpreters must not simply bring their own language habits and thinking patterns into the target language, or it would be easy to produce non-standard interpreting output and influence understanding. In this case, the difficulty lies in the interpreting of “三大传统优势产业和新兴产业”. It should not only conform to the source language structure characteristics and in the target language for the audience to understand, so does the interpreter have "traditional" and "emerging" in the target language text to bring out the best in each other. In addition, the technical terms like “鱼类养殖” and “航空航天” are fallible, which also requires the combination of the daily accumulation and flexibility of the interpreter.

Source Text of Example (3): 今天我市在此举行核心项目招商推介签约仪式, 有幸能向各位介绍我市 现有的关键项目各项信息，希望向参会拨光光临的领导来宾致以热烈欢迎和崇高敬意!

Reference Interpreting: We would like to extend our greatest welcome to all the leaders and guests who participate in the Signing Ceremony of Key Project Promotion Meeting of our city with the privilege of 
introducing the information of our key project.

There are several notable four-letter Chinese words in this sentence like “拨光光临”, “热烈欢迎”, and “崇高敬意”. The interpreter in the relevant tasks will typically seek equivalence transformation, but the real implementation of language adaptive transformation requires careful analysis of the source text structure for its deep meaning and reduces the constraints of the source language. In consecutive interpreting task, time is extremely limited so that the interpreter can use notes to find out the central meaning with their own reasonable interpretation to ensure that the target audience grasps the intention of the speaker.

\section{Adaptive Selection and Transformation Strategies From Cultural Dimension}

In cultural adaptation transformation, interpreters need to realize their own responsibilities and roles in the relevant tasks, namely the expression and explanation of mother tongue and target language's cultural connotation during the whole working process, and finally realize the cultural dimension conversion, which stresses on the avoidance of interpreter's misunderstanding caused by his own cultural perspective (HU, 2004). Therefore, the interpreter in the tasks should not only achieve successful transformation of the target language on the basis of understanding the source language, but focus more on the target language's cultural ecological environment to achieve the harmonious unification of bilingual transformation. In this section, three typical interpreting cases are selected from the investment promotion conference of a county-level city in 2015, and the specific analysis and reference interpretation are as follows:

Source Text of Example (1): 在本次活动即将结束之际, 衷心祝愿各位嘉宾身体健康，萳家欢乐，事 事顺心! 再次感谢大家的光临！

Reference Interpreting: Last but not the least, we wish all guests and friends well from the bottom of our heart. Thank you.

The lexical meanings between different cultures vary in interpreting activities and linguistic transformations are also influenced by cultural factors. In view of this, interpreters should give full play to their subjective initiative in consecutive interpreting tasks and overcome cultural differences and deficiencies existing between source language and target language to accurately express relevant information. In this case, the seminar and other similar meetings are often closed with words like “身体健康”, “萳家欢乐”, and “事事顺 心”, which are typical Chinese formal closing word structure, but in Western culture this is redundant.

Source Text of Example (2): 今天在座的朋友们, 我们衷心希望您能抓住这千载难逢的良机, 选择合 适的项目，与我市相关企业进行投资洽谈，通过贵我双方的精诚合作，最终实现双赢的目的。

Reference Interpreting: For all honorable guests here now, we sincerely hope that you can choose the proper projects and negotiate the potential investment and cooperation with companies of our city. Through our sincere and honest cooperation, a win-win situation is our final goal.

In the Chinese expressions, the blessing phrases are often in the pursuit of flowery language while not affecting the linguistic simplicity. The structure of the sentence often appears as a succession of adjectives and adverbs. But in the consecutive interpreting of government investment promotion, the interpreter should try to follow the target language and cultural characteristics. In this case, it is shown as in the last sentence “贵我双 方的精诚合作, 最终实现双赢目的” of the relevant processing to make the sentence concise and conform to the target language habits.

Source Text of Example (3): 近年来, 我们更新自身发展目标, 不断完善, 加快道路规划和建设、强化 城市管理, 目前城市服务功能日益成熟, 城市品牌知名度不断上升, 为广大来我市的投资者提供创造适 
宜的环境进行生活和投资，进一步彰显我市的鬼力和活力。

Reference Interpreting: In recent years, we update our development plan with the constant reform of road construction and city management. The service role and reputation of the city has been developing rapidly since then. As one of the wise investors in our city, you will embrace a comfortable environment to invest and live in.

From the linguistic form of source language and target language, the adaptive selection of cultural dimension shift is more focused on the transformation of cultural connotation at the linguistic level. The interpreter should take the initiative to grasp the language and cultural system of both source language and target language from the perspective of analyzing the cultural property and focus on the concrete analysis. In this case, expressions like “城市品牌知名度” and “魅力活力” are rarely mentioned in the English speeches, so the interpreter should be careful and avoid ambiguity. For the sake of accurate expression, it is acceptable to use their discretion for omission or adaptation.

\section{Adaptive Selection and Transformation Strategies From Communicative Dimension}

In the transformation of communicative dimension adaptability, the focus of the translator should focus on whether the bilingual communicative intention is adapted and transformed in the process of interpreting (HU, 2010). Limited by meeting agenda and interpreter's energy, relevant consecutive interpreting tasks contain multifarious language and cultural information content and ask the focus shift on to the target language output and reach a final communicative purpose. This section selects three typical interpreting conversion cases of an annual investment promotion meeting of a Chinese city in 2016 and the specific analysis and reference interpretation are as follows:

Source Text of Example (1): 引进高端先进设备的相关企业, 我市将给予 $10 \%-15 \%$ 的高额补贴, 企业 通过各种渠道引进的高端人才, 我市将免费提供专家公寓, 确保企业发展。

Reference Interpreting: For the development of enterprises, we will grant a $10 \%$ to $15 \%$ subsidy to enterprises buying new advanced equipment and free expert apartments for those introducing high-end talents.

One of the fundamental tasks of the roadshows is to promote bilateral communication, so it is an important factor to consider whether the communicative intention can be achieved by interpreters, who should transform not only the linguistic and cultural information mentioned above, but also the last indicator of success in the tasks. In this case, the source language is slightly redundant for the description of “补贴” and “人才引进”, "subsidies" and "talent introduction", and thus the interpreter should choose the neutral and objective description to make the communication more smooth.

Source Text of Example (2): 我市已开工建设的大型多功能国际物流园区, 设计园区面积达5000亩以 上，目前已投资100亿元人民币，待2018年全部建成后将拥有国内外货运专线1000多条，并实现年均货物 吞吐量5000万吨以上。

Reference Interpreting: The construction of a large multifunctional international logistics park has been started with area over 333.3 hectares and 10 billion yuan investment. There will be over 1,000 freight lines in China and abroad and over 50 million tons of annual cargo throughputs when the park is built in 2018.

When dealing with numerical information, the interpreter should first pay attention to the unit differences and figure interpreting skills between English and Chinese in the limited time. To achieve successful communication purpose, thinking patterns of target audience should be also considered. For example, there is a Chinese unit “亩” in the source text while westerners prefer "hectare”. So the interpreter has the responsibility 
to convert relevant units into the target language counterparts, reduce communication difficulty to the greatest extent, and promote the communication of both sides.

Source Text of Example (3): 首先我想感谢各级领导和有关部门的大力支持, 因此我们的行业发展才 走上了今天的快车道, 有了今日的辉煌。同时我呼吁在天南海北奋斗在各行各业的我市精英, 对家乡的 发展给予更多关注, 以各种方式对家乡建设助力加油。

Reference Interpreting: Firstly, I would like to show my gratitude to all the leaders and related departments for your continuous support. Without that, it will be difficult for us to enjoy such a success of our industry. At the same time, I would call for all the talents from our city who work all over the world to pay more attention to our city's development and make contribution in various ways to our hometown.

Cultural information transformation is the responsibility of the interpreters, so they should focus on their output, complete in the expression of cultural content, and avoid fallacy of composition and self-orientation (ZU, 2007). In this text, the speaker expresses his gratitude to the state aid and calls on the talents in the other places to devote their efforts in local construction. The interpreter should make appropriate supplement in interpreting and allow people who are not familiar with the Chinese people conversation thinking logic to have a better understanding to realize a more effective communication.

\section{Conclusion}

Based on the "three-dimensional" transformation theory of eco-translatology, this article analyses relevant consecutive interpreting cases and strategies of the promotion roadshows of Chinese government investment attraction and puts forward the related suggestions, making clear the role of interpreter in such tasks. To succeed in linguistic, cultural, and communicative dimensions, interpreters should accept appropriate choices of three-dimensional transformation. At the same time, the rules and requirements can be abided by interpreters to employ in the eco-translatology under the guidance of consecutive interpreting in the promotion roadshows of Chinese government investment attraction, by providing interpreting standard, task flow, and interpreter feedback aspects as reference.

\section{References}

Gile, D. (2011). Basic concepts and models for interpreter and translator training. Shanghai: Shanghai Foreign Language Education Press.

HU, G. S. (2004). An approach to translation adaptation and selection. Wuhan: Hubei Education Press.

HU, G. S. (2009). On the interpretation of eco-translatology in Fu Lei’s translation theories. Journal of Foreign Languages, 2 , 47-53.

HU, G. S. (2010). Eco-translatology: Backgrounds and bases for its development. Foreign Languages Research, 4, 62-67.

WANG, D. (2016). Consecutive interpreting. Beijing: Foreign Language Teaching and Research Press.

WANG, N. (2011). Eco-literature and eco-translatology: Deconstruction and reconstruction. Chinese Translators Journal, 2, $10-15$.

ZU, L. J. (2007). Eco-translatology in the context of globalization. Foreign Languages in China, 6, 89-92. 